\title{
The Impact of Regulations and Laws Governing on Solid Minerals Exploitation in Three African Countries: A Literature Review
}

\author{
Tamburo Michael Renzi \\ Business Management, LIGS University, Honolulu, Hawaii State, USA \\ Email: mr.tamburo@gmail.com
}

How to cite this paper: Renzi, T. M. (2021). The Impact of Regulations and Laws Governing on Solid Minerals Exploitation in Three African Countries: A Literature Review. Open Journal of Business and Management, 9, 512-526.

https://doi.org/10.4236/ojbm.2021.92028

Received: January 4, 2021

Accepted: March 2, 2021

Published: March 5, 2021

Copyright $\odot 2021$ by author(s) and Scientific Research Publishing Inc. This work is licensed under the Creative Commons Attribution International License (CC BY 4.0).

http://creativecommons.org/licenses/by/4.0/

\begin{abstract}
Mining companies from around the world play an important role in socio-economic development in Africa. These mining companies generate revenues for the governments, which create physical and social infrastructure and provide other essential services. However, this objective is not achieved in some cases due to many factors, including inadequate regulations and lack of enforcement of the mining codes. The purpose of this paper is to critically examine the environmental laws, rules, and mining codes that govern the exploitation of minerals like diamond and copper in Africa, as well as their relevance for the management of the mining companies by focusing on South Sudan, Rwanda, and Democratic Republic of Congo (DRC). Although Rwanda is not as mineral-rich as DRC and South Sudan, they all have a comprehensive mining policy that could make them a significant mineral processing and trading hub in the region. From this evaluation, it is evident that the government and mining companies have a major role to play towards environmental protection and local communities. The government of the day must enact policies and laws and ensure that they are effectively enforced. The mining companies must also adhere to the set environmental rules and efficiently use the available resources. In a nutshell, government, mining companies, and the local community must work together to attain a high-quality environment. This study aims to provide in-depth insights into various environmental laws and regulations and mining codes that exist in DRC, Rwanda, and South Sudan intended to protect the environment from the adverse effects of mining by examining whether mining laws have been relevant to mining operators.
\end{abstract}

\section{Keywords}

Mining Code, Environmental Protection, Environmental Regulatory 
Framework, Community Investment, Management Decisions, Sustainable Mining, DRC, South Sudan, Rwanda

\section{Introduction}

\subsection{Background}

Mining is one of the primary industries in sub-Saharan Africa. Most countries in Africa rely on minerals, such as diamonds, copper, and gold, as their primary source of revenue. However, the extraction of these minerals from the ground results in considerable environmental damages that pose risks to the communities and costly to clean up (International Financial Corporation, 2020). Some of these damages in sub-Saharan Africa include abandoned pits and shafts in artisanal mining areas in West Africa, dumps from previous mining activities in South Africa, pollution of ground and surface water, contamination of soil and loss of agricultural lands, air pollution, and risks of landslides (Pretty \& Odeku, 2017). These problems have led to accidents, diseases, and various challenges to the local population. To mitigate these risks from current and future mining operations, different countries in the region enacted mining codes and regulations, which promote environmental responsibility and sustainability in "miners" actions.

Nevertheless, some countries lag in enforcing such codes (Gasana et al., 2015). Therefore, this paper explores the environmental regulations and laws governing mineral exploitation in sub-Saharan Africa and their implications on the management of mining companies. The researcher focuses on the environmental regulations and enforcement in the Democratic Republic of Congo (DRC), South Sudan, and Rwanda.

\subsection{Research Question}

This study's primary aim is to provide in-depth insights into various environmental laws and regulations and mining codes that exist in DRC, Rwanda, and South Sudan intended to protect the environment from the adverse effects of mining. In doing so, the author examines whether these laws and codes have been relevant to mining operators in those countries. In a nutshell, the paper aims to answer the question:

- How are the enacted environmental laws and mining codes influencing mining companies' management activities and decisions in Africa in relation to environmental conservation and sustainability?

\subsection{Research Tasks}

To answer the research question, the author:

1) Gathered secondary data from books and past studies on the mining activi- 
ties and mining codes in Africa;

2) Critically evaluated data focusing on mining activities and laws in DRC, Rwanda, and South Sudan;

3) Examined the environmental regulatory framework in Rwanda, DRC, and South Sudan and assessed how they impact on the management of mining companies;

4) Compared the findings with those from other regions and international codes to make appropriate suggestions on how regulations and mining codes could lead to the mining companies' more sustainable management.

The rest of the paper is divided into three sections, i.e., theoretical background, method and findings, and discussion sections. The theoretical background section presents a description of environmental regulations and mining codes in DRC, Rwanda, and South Sudan. Methods and findings sections describe how the study was conducted and findings of an analysis of various regulations and codes. The research examines if the results answer the research question and impact on theory and practice in the discussion section.

\subsection{Research Methodology}

This paper mainly adopts a qualitative approach. A qualitative approach is an effective practical approach to making sense of the realities and describing and explaining the social world. It is also essential in developing theories or examining theoretical foundations (Sarantakos, 2012). This approach is consistent with this research's primary purpose, which is to critically assess the environmental regulations that impact mining activities in DRC, Rwanda, and South Sudan and their relevance for mining companies. This paper adopts a qualitative exploratory research design where data is collected majorly through qualitative literature and database analysis. The proposed qualitative research framework will be developed upon a standard methodology for constructing composite legal and regulatory indicators. The adopted qualitative theory-driven (top-down) over data-driven (bottom-up) approach will ensure that exploitation and sustainability of minerals in Rwanda, South Sudan, and DRC will be efficiently assessed by selecting ideal indicators. This means the author examines various environmental laws and mining codes in the three countries and determines how they affect different mining companies' operations.

The data used in this paper was gathered from secondary sources. To increase the effectiveness of the research, the secondary data was collated and summarized appropriately. The secondary data used in this study included a critical analysis of literature on the regulations and laws that govern the exploitation of minerals in Rwanda, South Sudan, and DRC, such as published journal articles, research reports, legal documents, as well as official websites of different organizations and a review of relevant laws and regulations currently in force (Sarantakos, 2012). The secondary data was accessed from the internet; most relevant information and organizations related to the regulations and laws that govern 
the exploitation of minerals in Rwanda, South Sudan, and DRC are uploaded on particular websites, digital libraries, journals, and social media. Global, national, and local organizations affiliated with mining, economic news delivery, and other web-based information relevant to this study was explored. All the literature and statistical data reviewed was acquired through internet searches. Secondary research was adopted as it is cheap and used already existing data. All the data used in the study were appropriately referenced to acknowledge the authors and publishers. The data gathered was then critically analyzed, and presented in the following section.

\section{Literature Review}

\subsection{Theoretical Background}

In many African countries, the regulatory framework and enforcement at both national and local levels are somewhat ambiguous. For example, in South Sudan, the constitution declares all the mineral wealth to belong to the central government. However, state and local authorities have been pushing for a more significant role in regulating mining activities within their areas. In a recent interview, the Eastern Equatorial State governor stated that the national government should only focus on policymaking and leave enforcement responsibilities to state and local governments (Pretty \& Odeku, 2017). Similarly, in Rwanda, there is a robust legal and regulatory framework in place for the mining sector: guidance for environmental impact assessments (EIAs), environmental monitoring, a checklist for mine inspectors is in place and being used by regulators and industry, and revised mining standards focused on health and safety have been drafted for approval (Kuschminder et al., 2017). In the DRC, various mining companies work with the local authorities, including rebel groups in Eastern Congo, to extract and smuggle different minerals outside the country. Without a proper regulatory framework, DRC's mining sector is considered a high-risk, high-return opportunity to international companies and local business people. The majority of the mining companies in DRC are Chinese companies. Like in DRC, China is the main importer of mineral sources from South Sudan. According to Kuschminder et al. (2017), African governments have a strong willingness to improve their mining sectors by updating and improving the mining legal framework and resulting mining policy as necessary; the governments take the lead on advancing and enhancing mining practices through the regular issuance of regulation orders and the periodic reviews of policies and guidelines.

By working with unscrupulous individuals, the government loses a significant amount of revenues to unscrupulous traders. Political and security risks, coupled with poor infrastructure, limit a country's capability to benefit from its vast untapped gold, cobalt, and copper reserves (Gasana et al., 2015). Focusing on DRC, Rwanda, and South Sudan, the following section assesses the three countries' regulatory framework. 


\subsection{Regulatory Environment}

\section{A. Democratic Republic of Congo (DRC)}

Environmental rights are captured in the Constitution of the DRC. For instance, Article 53 of the Constitution states that every person in the country has a right to a healthy environment. This implies that the state has a responsibility to protect the environment and the health of its people. The primary regulatory regime governing mining operations in DRC is the 2002 Mining Code (Ladu et al., 2019). The mining code has various stipulations on entire mining operation processes from acquisition to termination and protection of the environment and cultural heritage. Specifically, the exploitation permits provide the mining company with exclusive rights to explore, develop, produce, and export minerals. The permit allows the company to install machines, develop mineral exploitation infrastructure, and efficiently use the water and forestry resources within the mining perimeter (Vircoulon, 2016). It also allows the firm to process, market, and transport the extracted minerals. Apart from the mining code, DRC also ratified international environmental conventions on environmental protection, such as the Basel Protocol on Liability and Compensation, Convention on International Trade in Endangered Species of Wild Fauna and Flora, Kyoto Protocol, and Paris Agreement, among others (International Financial Corporation, 2020). These conventions mean that the DRC mining sector has to operate within the global standards of governance for oil, gas, and mineral resources.

Domestically, the Mining Code has faced some amendments, including the Mining Regulation of 2018, establishing enhanced environmental measures. The amendments also created a principal regulatory body, the Department for the Protection of the Mining Environment (DPEM), tasked with enforcing laws on mining environment protection (Nachmany et al., 2015). Despite these regulations and authority, several mining companies in DRC continue to receive preferential treatment due to historical and political reasons. Whereas legislation empowers the government to expropriate in the public interests, many companies and business people still operate in a manner that leads to significant damage to both the environment and society (Deng et al., 2013). This shows that enforcement of the Mining Code and the environmental laws and conventions is potentially still weak in DRC.

\section{B. Rwanda}

As shown in Figure 1, mining is not one of the leading economic sectors in Rwanda. Nevertheless, the government remains committed to developing appropriate mining policies that target local resources and resources from neighboring countries like DRC.

Environmental management in Rwanda is governed by the National Environment Policy. The policy sets the goals of environment management at both the national and local levels consistent with the nation's objectives of good governance and decentralization (Samndong \& Nhantumbo, 2015). The policy also establishes institutional and legal frameworks that guide the coordination of different 


\begin{tabular}{|c|c|c|c|c|c|c|c|c|c|c|c|c|}
\hline \multicolumn{2}{|l|}{$\begin{array}{l}\text { Gross Domestic Product } \\
\text { by Kind of Activity } \\
\text { Share at Current Prices }\end{array}$} & & & & & & & & & & & \\
\hline \multicolumn{2}{|l|}{ (Percentages) } & 2007 & 2008 & 2009 & 2010 & 2011 & 2012 & 2013 & 2014 & 2015 & 2017 & 2017 \\
\hline Activity Description & ISIC4 & 2006-07 & $2007-08$ & 2008-09 & $2009-10$ & $2010-11$ & 2011-12 & $2012-13$ & 2013-14 & $2014-15$ & $2015-16$ & 2016-17 \\
\hline $\begin{array}{c}\text { AGRICULTURE, } \\
\text { FORESTRY \& FISHING }\end{array}$ & A & 33 & 30 & 29 & 29 & 28 & 28 & 29 & 29 & 28 & 28 & 31 \\
\hline INDUSTRY & B-F & 14 & 15 & 14 & 14 & 15 & 16 & 17 & 17 & 17 & 17 & 16 \\
\hline TOTAL MANUFACTURING & $\mathrm{C}$ & 6 & 6 & 6 & 6 & 6 & 6 & 6 & 6 & 6 & 6 & 6 \\
\hline SERVICES & G-T & 45 & 48 & 49 & 49 & 48 & 48 & 47 & 48 & 48 & 47 & 47 \\
\hline $\begin{array}{c}\text { Source: National Institut } \\
\text { of Statistics of Rwanda } \\
\text { September } 25,2017\end{array}$ & & & & & & & & & & & & \\
\hline
\end{tabular}

Figure 1. Annual GDP percentage contribution by the leading economic activities and sectors of the Rwandan economy between 2007 and 2017. Source: UNESCO (2018).

sectors and innovations. Concerning mining, the policy framework stipulates how the environmental impact assessments, monitoring, and checklists are conducted. The mining standards must also ensure the protection of the health and safety of people in the community. Rwanda's government is also committed to improving the mining sector by regularly issuing ministerial orders and periodic reviews of various guidelines and policies. Rwanda seeks to become a regional hub in mineral services through these legislations due to its proximity to mining areas (IGF, 2017). Compared to DRC, enforcement of the environmental regulatory framework in Rwanda was found to be more effective.

\section{South Sudan}

Despite being a party to the Paris climate agreement (COP22), South Sudan does not have a national environment policy or legislation. The country has been working with regional partners and the United Nations Environmental Program (UNEP) towards developing the policy. Nevertheless, the Mining Act of 2012 and the Petroleum Act of 2012 stipulates how mining companies should conduct their operations in the country (Pretty \& Odeku, 2017). These acts were drafted and enacted in accordance with Articles 55 and 177 of the Constitution of the Republic of South Sudan, which provided for the sustainable use of natural resources and environmental protection.

The Mining Act governs large-scale and small-scale mining, including issuance of exploration, reconnaissance, and large-scale mining licenses. Upon the passage of this Act, the government repealed 53 licenses granted by various state governors. The Act also established various institutions to support the mining industry. These institutions included the Ministry of Environment and Forestry, Lands Commission, Directorate of Mineral Development, Ministry of Mining, and Directorate of Geological Survey, among other related institutions (Deng et al., 2013). These institutions offer support to the mining companies to ensure optimal exploitation of natural resources. 
In general, the ultimate goal of the Mining Act of 2012 is to promote and facilitate exploring, developing, and production of mineral products in South Sudan within the sustainable development principles. This implies that various mining stakeholders' decisions should correspond with respect for health protection and management, and ensure that the environment and the natural resources are preserved for future generations (Ladu et al., 2019). The Act was also to ensure effective management of mining waste by-products by emphasizing re-use and recovery and reducing the by-products. The waste management activities must be conducted to protect and enhance the land's quality of eco-systems and restoration. The Act encourages research on mineral extraction and production processes so that the tools or techniques used can improve productivity, competitiveness, and efficiency of the mining industry while ensuring a reduced adverse impact on the environment. Other related regulations to mining and environmental protection include the international convention, such as Polluter Pays Principle 1974 (CORDAID, 2016). Like DRC, South Sudan has struggled to effectively enforce different provisions of the Mining Act 2012 and other environmental laws. In this regard, South Sudan people continue to be exposed to mining activities' adverse effects within their society.

\section{Findings of the Critical Literature Review}

\section{Challenges to Implementation of Environmental Legal Framework and Mining Codes}

In most sub-Saharan African countries; laws are established with the primary objective of attaining a credible and sustainable governance framework, which regulates the extractive practices of private companies and assists the governments in the proper management of the mineral resources (International Alert, 2009). Rwanda is one example of countries in the region that have developed robust mining policy. According to IGF (2017), the mining policy is intended for minerals in Rwanda and position the country as a mineral processing hub. Nevertheless, the majority of the countries in the region still lack such comprehensive policies. For instance, both the DRC's Mining Code 2002 and South Sudan's Mining Act of 2012 identified several opportunities for greater accountability and transparency in mining operations management. In licensing, exploration, revenue sharing, resource allocation, and contracting and extraction, the regulations demanded greater transparency from both the companies and the government agencies (Pretty \& Odeku, 2017). However, one must acknowledge that both countries' violent clashes have complicated the governance processes and reduced their capabilities to invest in innovative strategies that can link resources to socio-economic development.

Undeniably, there is ambiguity on the distribution of regulatory authority between the Ministry of Commerce, Industry, and Investment, and the Ministry of Petroleum in South Sudan. The two ministries see investors' attraction and 
facilitation of investment in the country as their core responsibilities (Ladu et al., 2019). In its medium plan, the Ministry of Commerce identified mining as a priority sector and published a guideline on how companies will operate in the industry and their eligibility for tax breaks, export duty exemptions, and government grants. Besides, in both DRC and South Sudan, it isn't easy to know who owns the mines. This is because of the overlapping legal systems. Like most of the Sub-Saharan countries, traditional institutions are primarily opposed to property rights acquisition. In the chiefdom-based societies of Eastern Congo, property rights are inherited (Vircoulon, 2016). While during the colonial period, the administration relied on chiefs for administrative responsibilities, in post-colonial Congo, chiefs no longer possess such powers. For instance, the state took full legal responsibilities over land rights due to the Bakajika Law of 1966, which was later amended as the 1973 Land Act (CORDAID, 2016). Despite this law's existence, the government of DRC is unable to apply them in practice leading to a blurry legal situation on land rights.

In both DRC and South Sudan, there exists a double system of law created by unending conflicts. For example, there is confusion on land rights between the government in Kinshasa and local communities in DRC. In South Sudan, the states insist they have powers over mining activities under their jurisdiction (Vircoulon, 2016). This confusion locks the land market, creating an opportunity for illegal mining activities, which do not adhere to the set environmental regulations and the mining codes. In both countries, the land is owned by cattle herders, politicians, and even army officers, who make it hard for the mining companies to gain land rights to operate. In DRC, land title transactions tend to follow political changes. For instance, Tutsi Rwandans were favored under the RCD-Goma administration. In the meantime, the Mining Code 2002 introduced mining rights, which are different from land rights (International Alert, 2009). Under the Code, mining companies gained their operation license from the mining registry instead of the land registry. Whenever mining licenses have been granted, land titleholders were limited from seeking compensation.

By assessing exploitation and mining online literature sources and government databases of Rwanda, South Sudan, and DRC, the challenges in the implementation of environmental legal frameworks and mining codes are similar across the continent of Africa. According to Mutagwaba (2006), the problems limiting effective enforcement of the regulations in most African nations result from the weaknesses inherence within the legislations and those associated with the system responsible for its execution. As a result, regulation and management in the mining sectors are more dependent on corporate responsibilities of mineral rights owners who have international reputations to protect and/or are obliged by conditions of their financiers (Nalule, 2019). The environmental regulation and laws that govern the exploitation of minerals in Africa face many constraints, including challenges to legitimacy, limits to administrative reach, and corruption. According to Gouldson et al. (2014), the generic challenges in the 
regulation of mineral exploitation include access to land and resources and the industry's social license to operate. Besides, the products' prices continue to fall, and the industry's ability to internalize the costs of meeting social and environmental expectations are being compromised (Gouldson et al., 2014). Many of the problems associated with the exploitation of minerals in Africa are exacerbated by the government's and industries' lack of credibility as responsible players (Nalule, 2019).

Comparing Regulatory and Accountability Initiatives in the DRC and South Sudan Mining Sector

While DRC and South Sudan have massive mineral resources, the two countries have been engulfed in conflicts for several decades. As a result, the environmental and mining frameworks have been weak, leading to adverse effects on the environment and high poverty levels. The governments have also not been able to generate sufficient revenues from the sector to develop social and physical infrastructure that can improve the country's quality of life (UNDP, 2018). There have been various initiatives at the national and international levels to improve regulations and mining accountability in DRC and South Sudan to address this problem. At the national level in DRC, these initiatives begin with the promulgation of the 2002 Mining Code, followed by the 2003 Mining regulations. The Code identified the Ministry of Mines, Mining Division, and Mining Survey Department as the only agencies tasked with regulating the mining sector. These agencies were also responsible for protecting the mining environment (Nachmany et al., 2015). The Code also established a baseline for calculating taxes, customs duty, and other payments from the minerals trade. Unfortunately, the regulations under the Mining Code 2002 have never been fully enforced. According to a recent report by the World Bank, it was noted that Cadastre Minier (CAMI) was not transparent in issuing mining permits, and some companies were favored (Bizoza \& Umutoni, 2012). Corruption was also a major impediment to the full implementation of the Mining Code and demanded greater environmental responsibility and accountability from the mining companies. In South Sudan, the Mining Code 2013 empowered the government to manage and regulate all the mining activities and ensure that these activities are conducted to ensure responsibility and accountability to the environment (Ladu, Athiba, \& Demetry, 2019). Like in DRC, these mining codes' enforcement has been poor due to conflicts and disagreements with local authorities.

International organizations, such as the OECD and United Nations, continue to show interest in mining companies' operations, environmental regulations, and enforcement of such regulations in unstable regions of DRC and South Sudan. Specifically, the OECD's guiding principles for companies operating in foreign countries included adopting corporate behavior that respects human rights, commitment to fighting corruption, paying taxes to the host nation, and disclosure of information regarding their activities (Pretty \& Odeku, 2017). The United Nations Panel of Experts also warned that international businesses in these 
countries were neglecting their environmental obligations and instead got involved in the country's political and ethnic conflicts. In this regard, the United Nations suggested that the companies' governments must ensure that the companies do not violate the OECD guidelines. Since 2000, the United Nations Security Council has also passed multiple resolutions in relation to the exploitation of South Sudan's natural resources (IGF, 2017). The resolutions include the recommendation that member states encourage mining companies under their jurisdiction to exercise diligence in Congo's operations.

Based on the comparative study on DRC and South Sudan, the quality of national governance in Africa's continent is undoubtedly a key ingredient in the success of the mining sector (Campbell et al., 2004). Past reforms of African mining codes have the potential to drive down standards in areas of critical importance to social and economic development and protect the environment in the countries concerned. Regulations and mining code reforms in Africa seek to demonstrate that no amount of local governance is sufficient if it is not accompanied by legal and fiscal frameworks designed to meet development objectives and implemented in the context of good international policies and rules (Campbell et al., 2004). The current regulations of redefining the role of the state through the introduction of increasingly standardized legal and fiscal frameworks intended to create a favorable investment environment, but at the expense of the state's capacity to respond to the challenges of development, are neither viable nor in the interest of local populations or of foreign investors (Campbell et al., 2004).

\section{Discussions}

\section{State of the Environment Laws in Sub-Saharan Africa}

Sub-Saharan African countries, such as the DRC, suffer from many environmental problems, such as soil erosion, degradation of wetlands, and deforestation. Some of these environmental issues were caused by reckless or irresponsible mining activities (KPMG International, 2014). For instance, miners were found to have left mining pits and dump sites, polluted water, and air. In the case of DRC, this was attributed to poor enforcement of environmental regulations and mining codes. While the sub-Saharan mining industry has historically received the largest share of the foreign direct investments in the region, In DRC and South Sudan, poor policies, lack of investment in the community, and political risks mean that people have remained relatively poor. Studies suggested that people in these regions still lack essential services, such as clean water. Some scholars cited that these problems are still as common as the existing environmental policies, and mining codes have been ineffective (Bizoza \& Umutoni, 2012). The ineffectiveness of these laws results from a lack of political will in addressing pollution problems from mining activities.

Regulatory authorities also remained oblivious of environmental quality deterioration. This has led the international community, such as the United Nations 
and OECD, to be more involved in environmental protection in the area. United Nations urges countries, such as DRC, to integrate environmental protection as a critical pillar of their sustainable development strategies (Pretty \& Odeku, 2017). The findings of this study show that national governments and local authorities have an essential role in promoting sustainable development and improving environmental quality while ensuring that the mineral resources positively impact the lives of all members of society. Sub-Saharan African governments should implement their environmental laws and mining codes and set appropriate investment priorities. For instance, in the mining areas, the state should provide clean water, collect and dispose of solid waste, offer education and health care using the revenues generated from mining activities (UNDP, 2018).

Moreover, the state should set comprehensive but realistic environmental standards consistent with its socio-economic circumstances (Gisore \& Matina, 2015). Most importantly, the standards should ensure a healthy environment while removing loopholes, which lead to economic distortions like illegal taxation and corruption. The set laws must be followed by a stringent commitment to enforcement by different concerned agencies.

\section{Management Implications for Mining Companies}

Based on the evaluation of mining companies' role in DRC and South Sudan, given the weak regulatory regimes, their role in sustainable development must be under serious scrutiny. These findings are consistent with the criticisms from NGOs and other human rights bodies, which indicated that the mining companies were complicit in the irresponsible treatment of communities and their environment (KPMG International, 2014). In this regard, mining companies must do more towards better environment quality through corporate social responsibility or other means. Most importantly, these companies must adhere to the local environmental laws and mining codes. They desist from using corrupt means to obtain mining licenses or work with unrecognized groups to facilitate their mining operations. Citing examples of Palabora (South Africa) and Sadiola (Mali), mining companies should ensure that they are committed at the management level to improving their environmental performance (AZO Mining, 2019). For instance, the two companies have raised the environmental management profile to the board level. This means that the companies strategically invest in environmental management systems and research to contribute positively to the mining environment and the immediate society.

The mining operations analysis in DRC also revealed that companies participating in the mining sector did not engage in adequate social impact assessment and social management plans to determine how their activities will impact the local communities. Whereas the mining industry plays a crucial role in local communities' socio-economic development, they must consult with these communities during various stages of their project to attain optimal social gains (Pretty \& Odeku, 2017). Regular consultations will result in early diagnosis of 
potential problems that may lead to environmental problems. Therefore, mining companies must integrate regular communication with members of the public throughout the project's lifespan. Regular communication also helps the members of the public to understand the risks associated with mining activities and enhance their awareness of the actions to take in case of an emergency. Regular engagement would also help the company to gain public acceptance (Gisore \& Matina, 2015). This engagement should also include the company making its environmental audits public.

Community investment should be an important component of the management policy of mining companies in sub-Saharan Africa. Usually, the mining companies are expected to, impact poverty and other socio-economic aspects of the community positively. As highlighted earlier, the company's contribution to the community living standards will depend on its adherence to government regulations, such as environmental laws and mining codes (KPMG International, 2014). For example, in countries like South Africa and India, the government is mandated to demand social investment plans before the mining companies can be granted mining rights (Dhawan, 2014). This policy intervention can be replicated, especially in DRC and South Sudan, so that these companies can participate in environmental protection and poverty eradication projects. There are also different areas, such as skill training, health, and agriculture assistance, in which these companies can invest (Dhawan, 2014). These programs reduce project-related risks and help the company to gain a social license to operate in the community. Stakeholder engagement is a crucial pillar of sustainable business strategy, and community investment helps the company to understand local needs and prioritize development projects appropriately (UNDP, 2018). One way of investing in the community and protecting the environment is ensuring that the resources are used efficiently. For instance, the mining industry in the United Kingdom is regulated by independent government regulators, particularly the Environment Agency (McKenzie, 2019). The critical legislation applied to ensure environment protection includes the Environmental Permitting (England and Wales) Regulations 2010, which implements Directive 2006/21/EC1 of the European Parliament and the Council on the management of waste from extractive industries (the "Mining Waste Directive"); the Environmental Protection Act 1990; the Wildlife and Countryside Act 1981; and the Natural Environment and Rural Communities Act 2006 (in England and Wales) (McKenzie, 2019). Mining companies must show commitment to using natural resources, such as water and fossil fuels efficiently. These companies should adopt process strategies that lead to minimal greenhouse gas emissions. In this regard, mining companies should invest in the environment and social management systems to assist them in risk and impact management. Management policies must be put in place to identify the impacts, set targets, and review continuous improvements (AZO Mining, 2019). The companies must acknowledge that efficient resources used would contribute to cost minimization and greater profitability. 


\section{Conclusion}

The mining sector is a significant attraction of foreign direct investments into sub-Saharan Africa. However, the mining operations of these companies have resulted in adverse environmental effects. These negative environmental impacts were attributed to inadequate environmental laws and poor enforcement of the existing laws and mining codes. This paper explored the environmental regulations and laws governing mineral exploitation in sub-Saharan Africa and their implications on mining companies' management. Reviewing the case of mining sectors in Rwanda, South Sudan, and DRC, it was found that the conflict-ridden DRC and South Sudan were ineffective in enforcing their mining codes and environmental regulations. This study indicates that dependence on natural resources is related to less democratic regime forms and worse governance institutions and outcomes in some African nations. In particular, there seems to be a correlation between natural resources and corruption and violence. Environmental crime and corruption are some of the most severe challenges confronting mining companies' management in some African countries. These nations are characterized by severe breach of a national or international environmental law or convention that exists to ensure the conservation and sustainability of the world's environment.

Conversely, Rwanda has a more comprehensive and effective mining regulatory regime. There is a need for the countries to follow Rwanda's footsteps in developing a comprehensive mining policy. Like Rwanda, other African nations need to formulate a robust legal and regulatory framework in place for their mining sectors: guidance for environmental impact assessments (EIAs), environmental monitoring, a checklist for mine inspectors to be used by regulators, and revised mining standards focused on health and safety have been drafted for approval. These governments should take the lead on advancing and improving mining practices through the regular issuance of ministerial orders and the periodic review of policies and guidelines. In a nutshell, the paper recommended specific management actions, such as engagement with the community and community investment, as part of their responsibility to the mining environment.

\section{Conflicts of Interest}

The author declares no conflicts of interest regarding the publication of this paper.

\section{References}

AZO Mining (2019). Supporting Environmental Waste Management in African Mining Companies. AZoMining.com. https://www.azomining.com/Article.aspx?ArticleID=1443

Bizoza, A., \& Umutoni, G. (2012). Socio-Economic Impacts of Rain Water Harvesting Technologies in Rwanda: A Case Study of Nyaruguru District, Southern Province. 
Rwanda Journal, 26. https://doi.org/10.4314/rj.v26i1.6

Campbell, B. K., Akabzaa, T. M., \& Butler, P. (2004). Regulating Mining in Africa: For Whose Benefit?

CORDAID (2016). Mining in South Sudan: Opportunities and Risks for Local Communities. Cordaid-Op de wereld om elkaar te helpen.

https://www.cordaid.org/en/wp-content/uploads/sites/3/2016/03/South Sudan Gold Mining_Report-LR-1.pdf

Deng, D. K., Mertenskoetter, P., \& Van de Vondervoort, L. (2013). Establishing a Mining Sector in Postwar South Sudan. USIP.

https://www.usip.org/sites/default/files/SR330-Establishing\%20a\%20Mining\%20Sector \%20in\%20Postwar\%20South\%20Sudan.pdf

Dhawan, R. (2014). Getting More Out of Social Investment in the Mining Sector. KPMG International.

https://assets.kpmg/content/dam/kpmg/pdf/2014/10/valuing-social-investment-mining -v3.pdf

Gasana, F. S., Mugerwa, T., \& Ndikumana, J. D. (2015). Assessment of Environmental Health Impact of Ores Mining Project in Nyaruguru District, RWANDA: A Perspective for Sustainable. International Journal of Advanced Research, 3, 1281-1287.

https://www.researchgate.net/publication/306118688 Assessment of Environmental Health Impact of ores mining project in Nyaruguru District RWANDA A persp ective for Sustainable Development

Gisore, R., \& Matina, Z. (2015). Sustainable Mining in Africa: Standards as Essential Catalysts.

https://www.arso-oran.org/wp-content/uploads/2014/09/Sustainable-Mining-in-Africa -Standards-as-Catalysts.pdf

Gouldson, A., Carpenter, A., \& Afionis, S. (2014). An International Comparison of the Outcomes of Environmental Regulation. Environmental Research Letters, 9, Article ID: 074019. https://doi.org/10.1088/1748-9326/9/7/074019

IGF (2017). IGF Mining Policy Framework Assessment: Rwanda. https://www.iisd.org/system/files/publications/rwanda-mining-policy-framework-asses sment-en.pdf

International Alert (2009). The Role of the Exploitation of Natural Resources in Fueling and Prolonging Crises in the Eastern DRC.

https://www.international-alert.org/sites/default/files/publications/Natural_Resources ذan 10.pdf

International Financial Corporation (2020). Sustainable and Responsible Mining in Africa.

https://www.ifc.org/wps/wcm/connect/14d1fb8c-8d63-47c9-acb7-35b20a488ff2/Sustain able+Mining+in+Africa.pdf?MOD=AJPERES\&CVID=knWL6Rr

KPMG International (2014). Democratic Republic of Congo: Country Mining Guide. https:/assets.kpmg/content/dam/kpmg/pdf/2014/09/democratic-republic-congo-mini ng-guide.pdf

Kuschminder, J., Bliss, M., \& Kasanga, C. (2017). IGF Mining Policy Framework Assessment: Rwanda. Intergovernmental Forum on Mining, Minerals, Metals and Sustainable Development (IGF).

Ladu, J. L., Athiba, A. L., \& Demetry, P. L. (2019). Environmental Impacts of Gold Mining: A Study of Mining Communities in Gorom Village, Rejaf County, Central Equatoria State, Republic of South Sudan. Applied Ecology and Environmental Sciences, 7, $1-10$. 
McKenzie, B. (2019). Environmental Regulations for Mining Activities in United Kingdom. Lexology.

https://www.lexology.com/library/detail.aspx?g=82852469-ce41-4c8a-98b6-ccd4952699 $\underline{\mathrm{fa}}$

Mutagwaba, W. (2006). Analysis of the Benefits and Challenges of Implementing Environmental Regulatory Programmes for Mining: Tanzania Case Study. Journal of Cleaner Production, 14, 397-404. https://doi.org/10.1016/j.jclepro.2004.02.045

Nachmany, M., Fankhauser, S., Davidová, J., Kingsmill, N., Landesman, T., \& Rappongi, H. (2015). Climate Change Legislation in Democratic Republic of the Congo. https://www.lse.ac.uk/GranthamInstitute/wp-content/uploads/2015/05/DRC.pdf

Nalule, V. R. (2019). Regulation of Mining in Africa. In Mining and the Law in Africa (pp. 19-50). Berlin: Springer. https://doi.org/10.1007/978-3-030-33008-8 2

Pretty, M., \& O. Odeku, K. (2017). Harmful Mining Activities, Environmental Impacts and Effects in the Mining Communities in South Africa: A Critical Perspective. Environmental Economics, 8, 14-24. https://doi.org/10.21511/ee.08(4).2017.02

Samndong, R. A., \& Nhantumbo, I. (2015). Natural Resources Governance in the Democratic Republic of Congo: Breaking Sector Walls for Sustainable Land Use Investments. IIED. https://pubs.iied.org/pdfs/13578IIED.pdf

Sarantakos, S. (2012). Social Research. Macmillan International Higher Education.

UNDP (2018). Managing Mining for Sustainable Development.

UNESCO (2018). Country Profile: Rwanda. UNESCO. Building Peace in the Minds of Men and Women.

Vircoulon, T. (2016). Behind the Problem of Conflict Minerals in DR Congo: Governance. Crisis Group.

https://www.crisisgroup.org/africa/central-africa/democratic-republic-congo/behind-p roblem-conflict-minerals-dr-congo-governance 